\title{
Africa after the Cold War: New Patterns of Government and Politics
}

\section{Stephen Ellis}

\begin{abstract}
-
ABSTRACT

The state-system of Africa is still essentially the one created by the colonial powers and passed on intact at independence. But the political economy of these states - the substance of political life within fixed territonal boundaries - is changing very profoundly as a result of the breakdown of the style of government of recent decades and the decline of economies based on the export of primary commodities. The political economy which is emerging, still within the same territorial boundaries, is best understood by reference to Africa's history over a long period.
\end{abstract}

Fundamental changes are taking place within the African state-system which is still, in essence, the one created by the colonial powers and inherited at independence by the governments of modern Africa (Davidson, 1992). Powerful forces in the industrialized world continue to have a crucial influence on events in the African continent, partly by means of the communication and information technology which is doing so much to reshape the world as a whole. The relationship between African elites and those in industrialized countries remains a key determinant in the distribution of power. Whether, on balance, the external forces affecting Africa's politics are more important than the internal ones is a matter which will not be debated here: it is the manner in which the two combine which is the focus of analysis in this article. ${ }^{1}$ In the following pages, we will attempt to identify some of the key features of the emerging political economy of Africa, while discussing various interpretations within the literature.

There is a large academic literature on the state in Africa, dominated in recent decades by specialists in political science with notable contributions from the study of anthropology and history (Chabal, 1992: 11-32). For much of the first period of African independence, say from the early 1960s until the late 1970s, the tone of writings on the subject tended towards

I am grateful to Bernard Berendsen, Deborah Fahy Bryceson, Martin Doornbos, Frédérique de Man and Gavin Williams for comments on earlier drafts of this text. It represents the situation in Africa at the time of writing, that is, in July 1995.

1. For a review of the literature on this subject, see Cooper (1993).

Development and Change Vol. 27 (1996), 1-28. (C) Institute of Social Studies 1996. Published by Blackwell Publishers, 108 Cowley Rd, Oxford OX4 1JF, UK. 
optimism, reflecting the widely-held view that African states were embarking on a simultaneous project of nation-building and economic development. Subscribers to the then-influential school of dependency theory suggested that such problems as they identified in the structure and functioning of African states would gradually disappear as governments managed to lessen their dependency on the industrialized world and the former colonial powers. Above all, perhaps, analysis of the African state was for some years based implicitly or explicitly on the assumption that the more African countries developed, or the more modern they became, the more they would tend to look like their European or North American counterparts: the paradigms of institutional analysis tended to be those derived from political theory rather than from close observation of African history or society. This was not surprising since African leaders represented themselves as modernizers above all else. It was only when writers confronted the evidence of economic failure and its attendant pathology in the 1980s that it became more common to encounter descriptions and analyses which implied a trenchant criticism of African states and the elites which governed them. Arguably the most important shift in the terms of this debate came with the publication in 1989 of the influential L'État en Afrique (Bayart, 1989/1993). It is sub-titled la politique $d u$ ventre ('the politics of the belly'), a term which alludes both to the extraordinary acquisitiveness of African political elites and to notions of sorcery associated with the acquisition of power in many parts of the continent.

The best way of examining these and other arguments on the African state is by reference to the recent historical experience of African states. However, before engaging in a discussion of recent developments in the African statesystem, referring where appropriate to individual examples, it is useful to dwell briefly on the vexed question of which examples to choose, and on the usefulness of extrapolating from case-studies.

\section{OPTIMISM AND PESSIMISM: AN UNHELPFUL DICHOTOMY}

Any serious discussion of the African state-system must surely pay at least some attention to Somalia, Rwanda, Burundi and Liberia, the countries with the most harrowing recent history in Sub-Saharan Africa. The point of mentioning these unhappy countries is not, it should be emphasized, in order to suggest that all of Africa is about to undergo the same trauma. Almost any serious statement about events in Rwanda, for example, in the course of a general essay on Africa, risks being interpreted in some quarters as a sign of a wider pessimism about the continent. It may be argued that more hopeful examples of what is happening can be found elsewhere, such as in South Africa, or in countries which are quietly getting on with business as usual, such as Botswana or Zimbabwe. This is true enough, but consideration of this point risks ensnaring an essay on the state-system of Africa in a highly subjective argument about the relative merits of optimism and pessimism.
From an analytical point of view, this is not of central concern. Worse, debate between optimists and pessimists inadvertently reinforces some common misperceptions about the real nature of events in Africa. All politics are partly about presentation or representation, but in Africa the representation of events in a certain light to the industrialized world is more than usually important because it has a direct bearing on a prime source of revenue of African elites, namely foreign aid. Some twenty-five years ago, one author pointed out that it was often regarded as poor taste to mention in print the subject of corruption in Africa, since this implied that the writer held a generally pessimistic view of African politics (Andreski, 1970: 346-7). The further implication at that time was that the holder of such an opinion was probably on the political right, possibly a nostalgist for colonial rule, certainly non-progressive. Concern not to offend certain post-colonial notions of propriety prevented some gifted commentators from addressing key issues of African politics during the Cold War period (Leys, 1994).

Nor has the end of the Cold War altogether removed the ideological factors (if 'ideological' is the right word) which can inhibit writing on Africa. There has, however, been something of an ideological switch. Whereas during the early years of African independence jeremiads on Africa tended to be considered politically inappropriate by radicals or Marxists, in recent years it has been proponents of free market economics and Western democratic models who have tended towards optimism, while those with a background in Marxist or 'Third Worldist' thinking, whether inside or outside Africa, are temporarily bereft of constructive arguments and thus risk being labelled as pessimists. Any author who does not possess an ideology which provides a sense of linear development risks being assigned to a category sometimes called 'Afro-pessimism' (Callaghy and Ravenhill, 1993:

1-17), a term which implies an ideology or at least membership of a specific intellectual school, despite the fact that no such school really exists at least in the academic world. Pessimism is commonly considered by academic writers on Africa and by development professionals as vulgar, a mode of debate worthy only of the much-maligned media.

The attribution of special ideological and moral values to Africanist discourse dates from pre-colonial times, when Africa came to acquire a particular moral dimension in the minds of Europeans and North Americans (Curtin, 1964). As Eric Hobsbawm notes, the moral imperative to help the poor world is an important and enduring element of the European political tradition which emerged from the Enlightenment. During the Cold War, the European Left, including social democrats and liberals, invested much of its idealism overseas. Support for revolution - and, one might add, for humanitarian work - in the Third World became 'the late-twentiethcentury equivalent of the support of missionary endeavour in the nineteenth' (Hobsbawm, 1994: 437). This phenomenon has very special political implications in the case of Africa since one of the characteristic features of the continent since the end of the colonial period has been its status as a recipient 
of massive international financial and technical aid. This aid is generally justified to Western publics on moral grounds; Western journalism has tended to allocate a special place to Africa, particularly since the Ethiopian famine of $1984-5$, as the continent of disasters. Aid has played a crucial role in sustaining and financing African elites and even entire states, which have often become dependent on it in one form or another as a source of income. Moreover, aid has become ever more tied by donors to the satisfaction of specific requirements. Thus, the moral coherence of certain types of argument in donor countries has a direct impact on relations between the rich world and African elites and on the policies which the latter may be required to implement. The desire to identify positive developments in Africa for reasons which arise from this particular moral calculus can colour technical judgements. These in turn can affect the policies of the donors which have such an important role in African politics.

Perhaps the most important recent example of this process at work concerns democracy in Africa. Before the late 1980s, there was relatively little written on this subject, since it was generally held in Europe and North America to be in bad taste to write in support of multi-party democracy in Africa explicitly, despite the evidence that brave people in Africa were willing to risk their lives and liberty for freedom. ${ }^{2}$ In Africa, until the late $1980 \mathrm{~s}$, it required exceptional courage to criticize the one-party state directly. ${ }^{3}$ Donor governments and aid agencies generally tried to avoid comment on domestic political arrangements, with the instructive exception of South Africa which in contrast, became a litmus-test of moral and political righteousness. Particularly after the events of 1989 -90 , however, this mood changed rapidly and fundamentally among Western commentators, donor governments and aid agencies. There was a flood of literature both in the popular and the academic press about democracy and governance in Africa, most of it explicitly advocating the hope or belief that liberal democracy would open the way to an improvement in Africa's fortunes. A high proportion of such studies were encouraged or financed, directly or indirectly, by aid-donors in search of policies which would be politically effective (Buijtenhuijs and Rijnierse, 1993). In the peculiar world of aid, that meant that they must in the first instance be justifiable to the Western publics which pay for aid budgets. Optimism about multi-party democracy in Africa became de rigueur, as did interest in a new discovery for Africanists - 'civil society' (Bayart, 1983, 1986; Tripp, 1994). This had an immediate effect on aid programmes and, hence, on the African elites which are their main beneficiaries. In these circumstances it was not difficult to see that any assessment of the effects of democracy in Africa which tended towards pessimism risked

2. There were, however, occasional bouts of publication on democracy, notably during the brief and disastrous second republic in Nigena (1979-83). An outstanding exception to these remarks is Sklar (1983).

3. African examples include Anyang' Nyong'o (1987). being rejected by African political elites (not least because it could threaten a major source of income) and also by those in the West who had a vested interest in the aid and development business or whose political philosophy caused them to make ideological projections on what used to be called the Third World.

Chief among the vested interests concerned are the Bretton Woods nstitutions, the World Bank and the International Monetary Fund (IMF), Which have come to play a crucial role in the management of African economies. It is not surprising that they are generally to be found in the camp of the optimists on Africa, at least to judge from their public statements. The World Bank believes that its goal of 'sustainable poverty reduction'4 (George and Sabelli, 1994: 148) may be achieved through the application of free market principles allied to liberal political reform, reducing the role of the state in the economy and simultaneously making it more efficient: to use the familiar image, a leaner and fitter state. The most important application of this approach in Africa has been the structural adjustment programmes implemented in many African countries since the early 1980s (Toye, 1994). After more than a decade of structural adjustment in most of Africa, the Bank believes that, on balance, 'the stronger reformers in Africa have turned around the decline in economic performance and are growing for the first time in many years' (World Bank, 1994a: 131). However, in no African case can the World Bank point to a really unambiguous success for economic liberalization, not even when it is combined with its political twin. In the most successful cases, such as Ghana, structural adjustment policies have produced economic growth higher than the rate of population growth but have not reached the ultimate goal, which is to stimulate the flow of voluntary private investment funds. The currently satisfactory levels of economic growth are dependent on the continuing supply of credits which will one day have to be repaid.

The perceptions of Africa which prevail in the industrialized world are thius peculiarly liable to influence by subjective factors which distract attention from the realities concerned. Furthermore, African elites have an interest in manipulating these misperceptions for their own purposes. In Africa, the dialectical relationship between reality and its representation has been of more than usual importance for modern states, and it is the condition of these states themselves which is now, or should be, a central point of debate.

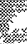

\section{THE DECLINE OF AFRICAN STATES}

All over the world, recent changes in financial techniques and communications technology, especially, have tended to erode national sovereignty. This

4. The phrase is attributed to World Bank president Lewis Preston. 
is particularly clear in Africa, where states have in general lost much of the political authority with which they were endowed by the act of independence. Since the fall of the Berlin Wall in 1989, symbolizing as it did the collapse of the Soviet bloc and of Marxism, free and fair multi-party elections have been widely regarded as the test of a government's legitimacy the world over. Africa is certainly no exception. African publics, like those in other parts of the world, followed with fascination the events in eastern Europe in 1989 via radio and television. They also followed with very partıcular attention the process of liberalization in South Africa. Parties which had existed underground for years dared to demonstrate in the open. Protestors took to the streets calling for an end to one-party tyranny. Before 1989 only a handful of African countries had had a multi-party constitution, but since then both domestic and international pressures have led African governments to adopt liberal constitutions.

The fall of the Berlin Wall coincided almost to the day with the publication of an important World Bank report, Sub-Saharan Africa: From Crisis to Sustainable Growth, which has had a major effect on the sub-continent. This document contained the Bank's first public reference to the need for 'good governance' in Africa and opened the way to a general call by donor governments for African governments to democratize (World Bank, 1989: 60). This stand by the World Bank, followed as it was by donor governments and other institutions, was generally applauded by African intellectuals as well as by most non-African commentators. The combination of domestic and international pressures was henceforth immense. Any African government which refused democratization risked having the financial tap turned off. ${ }^{5}$

A sympathetic observer might say that the assumption of liberal democratic norms has led to a perceptible change for the better in a number of countries, in the sense that the new dispensation has resulted in a reduction in political conflict and a better prospect of economic growth. This is most obviously so in the case of South Africa but also, for example, in Mozambique, Ethiopia, Zambia and Benin. A more sceptical commentator might concede that the emerging order in South Africa, though fragile, is indeed better than apartheid, and that the end of the wars in Ethiopia can be regarded only as an improvement, but that in Zambia, Benin and elsewhere, liberal democracy has simply provided a means for existing political elites to regroup. In none of the latter cases has the adoption of a multi-party constitution done anything to solve the underlying political and economic problems of the country. Meanwhile, in Togo, Kenya, Gabon and elsewhere,

5 Interestingly, one of the few African governments to have successfully resisted calls to adopt a multi-party constitution is Uganda, which has paradoxically emerged as a donors' favourite This may be partly explaned by the exceptional tactical skill of President Yowerı Museveni, but it is also a result of the widespread international perception that Uganda was a special case because of its need to recover from the disasters inflicted by presidents Idı Amin and Milton Obote. incumbent presidents whose fundamental suspicion of democracy is wellattested have in fact used the forms of liberal democracy to strengthen their hold on power. In Rwanda, there is a case to be made that the application of external pressure to democratize, coinciding as it did with the opening of an armed conflict, was one of the factors leading to the appalling genocide of 1994 (cf. Reyntjens, 1994: 258-9). President Mobutu of Zaire is another antidemocrat who has managed to survive the wave of democratization. In fact he is now probably more powerful than at any time since the late 1980s, chiefly because of the skill with which he has used events in neighbouring Rwanda to his own advantage. President Mobutu is a master at using his ability to stabilize or destabilize parts of central Africa as a means of securing financial and political support from Europe and the USA. The Rwandan tragedy has caused some in the donor community to wonder whether stability is not, in the short term, of more importance than democracy, and President Mobutu has taken advantage of this to play his trump card once more.

In retrospect, it seems clear that while democratization became an unstoppable force in the early 1990 s, it meant different things to different people. To incumbent African presidents, it meant a shift in the rules of the political game, but one to which the most skilful players were able to adjust. To ambitious politicians, it offered an opportunity to achieve high office by an appeal to popular and international opinion. Quite what it meant to African publics is not altogether clear due to lack of research, but, to judge from the publics is not altogether clear due to lack of research, but, to judge from the
enthusiasm with which multi-partyism was greeted in most parts of the continent, it certainly brought hope of a change for the better.

In the view of the World Bank and of the donor community generally it was accepted after 1989 that political and economic liberalization in Africa would bring progress and that they should accompany one another, although which might precede the other was not entirely clear. A basic assumption of this line of thinking is that reducing the heavy hand of the state in political and social life, just as in economic matters, will create opportunities for free associations of citizens to engage with the res publica. This is held to be both morally desirable and politically effective, especially when combined with the economic opportunities created by the establishment of free markets. The World Bank and the donor community generally believe that privatizing state or parastatal corporations and firing unproductive civil servants will help reduce the clientelism and corruption which got so many African governments into difficulties in the first place. Reducing clientelism and corruption ${ }^{6}$ may be laudable arms. The fact that they have been used as the main techniques of political mobilization and control throughout Africa for several decades is one of the main reasons for Africa's political and economic problems (Joseph, 1987, Médard, 1991); but it also

6. For definitions of corruption, see Heidenheimer et al (1989 3-68). 
makes the dismantling of these systems an exceptionally delicate business. The reduction of clientelist networks represented by the major retrenchment of public sector employees has therefore caused even more political problems than would be the case in a part of the world where political systems are less clientelist in nature. In the most extreme cases, the combination of these and other factors has weakened some African states to the extent that they can hardly fulfil the basic duties expected of them by the national community (that is, their own citizens) or by the international community. Such duties include maintaining an effective monopoly of violence over the national territory. A state which becomes chronically unable to do this, especially if it also loses the ability to levy taxes, risks losing the capacity to reproduce itself. In other words, a situation of this sort risks not only bringing down a specific government, but even destroying the state as an organ of power.

One may argue that if a government operating under a democratic constitution loses the confidence of its people then the people have only to vote it out of office, and that Africans now have this option thanks to democratization. However, a quick look at Africa reveals a number of obstacles to this. In countries like Mali, Sierra Leone, the Central African Republic and others the state has lost the power to perform some of its key functions, including that of exercising control over all of its national territory. The state itself, not just the government, may collapse to the extent that it is unable to organize elections, as in Somalia, Liberia or Rwanda. A logic of armed insurrection may take over to the extent that elections become barely relevant. Losers may reject election results, as in Angola. Most damning of all, the industrialized world may not like the outcome of elections and encourage their cancellation, as in Algeria. So it is that the World Bank and the donor community, in dogged application of an ideology, apply policies which may undermine African states and make even more difficult the attainment of that stability which they believe to be necessary for economic growth.

In all the countries mentioned above (with the possible exception of Somalia), although the state apparatus has lost the power to carry out many of its most basic functions, the state itself cannot be said to have disappeared. It still exists if only in the sense that there remains a residue of power at the national level, aspirants for which seek to occupy the position of president. This is still the ultimate prize. For the title of president can generally be expected to bring access to international resources and to enhance domestic prestige, even if it no longer implies control of a regular tax-base, a national army, or a civil service able to implement policies throughout the national territory. In the most extreme cases, a modern African head of state is, in certain respects, rather more like a pre-colonial 'big man' than he - for all are men - is like a European or North American president. President Mobutu, for example, controls a corps of fighters but not a coherent national army. He has no real civil service but a patronage network through which he can raise tribute-money from the people under his control and which he uses to enhance his prestige. A 'big man' can also use his prestige to raise tribute from other potentates and international traders (see, for example, Reno, 1993). It is significant in such cases that revenue-collection is not done through the modern method of using a bureaucracy to assess individuals' or companies' tax liabilities, but by requiring payment from lieutenants, who in turn require it from their underlings, who in turn extort it from the general population. This is the logic of such a patronage system. It is a pyramid, in which power and prestige flow from the top downwards, while wealth is simultaneously sucked from the bottom upwards; wealth or opportunities for advancement are redistributed within clientilist systems by the provision of gifts, commercial opportunities, and so on, to the supporters of political patrons. The donor community refers to such systems as a government or a state, and the head of the network is called the President. But as Filip de Boeck (1994) has pointed out, in the end this can encounter a semantic problem. Why should we call a certain large building in Kinshasa the Central Bank of Zaire when it has no money and fulfils none of the functions of a central bank? Why should we call a gang of armed thugs who prey on civilians for profit, as in Zaïre, a national army? Why, for that matter, should we refer to a self-serving clique which survives by racketeering and manipulation, as a government?

The short answer to these questions is that diplomatic convention and international law require us to use the vocabulary of statehood in regard to every member-state of the United Nations, the expression of the international order which dominated the world after 1945. Modern African states were born at the height of the world boom which followed the Second World War and they based their legitimacy on their claim to incarnate the legal principles of international order. The only states in Africa which were fairly consistently excluded from this moral order were those which offended against the prevailing ethos of national emancipation, most notably the apartheid state of South Africa. Perhaps African nationalism, in the circumstances of the 1950s and 1960s, was an early example of African and Western publics broadly agreeing on an idea - national sovereignty - but understanding radically different things by it, as is now happening with regard to African democracy.

It is clear that the heyday of African nationalism coincided with the system of order created after the Second World War, when for some decades it constituted an ideology which was both internationally acceptable and a redoubtable means of domestic political mobilization. The system of international relations established in 1945 has been undergoing profound changes since the end of the Cold War or, according to some perceptive analysts (Hobsbawm, 1994: 6), since the oil price rises and related phenomena of the 1970s. It is not surpnsing to see that African nationalism has declined accordingly. As the great Cold War power blocs have unfrozen, they have revealed all sorts of movements and patterns in various parts of the world Which many people thought had disappeared, or at least become outmoded. Just as the end of the Cold War in eastern Europe and the Balkans revealed a 
number of conflicts which had existed before 1914 but which most people had assumed to have disappeared, so too in Africa. Many political species which only a few years ago were thought to be endangered or extinct, such as Balkan warlords, Caucasian mountain-men and African 'big men', are discovered to be still in existence after all. They have survived the colonial period and the Cold War by going underground or disguising themselves as something else.

\section{THE LINEAGE OF AFRICAN STATES}

In many parts of Africa, for most of their known history and until only a century or so ago, people contrived to live together in recognizable political communities without powerful bureaucracies (indeed without literacy in many cases), without standing armies, sometimes without a single national language, without cities, without modern industry and without that degree of centralized government which most people today would probably regard as necessary for the definition of a state. It may even be argued that many of the political entities of pre-colonial Africa which historians have called states, like old Mali or old Kongo, were hardly states at all in any modern definition of the word. A Eurocentric historiography of Africa has sought to fit events into an inappropriate theoretical framework, which still obscures our capacity to understand Africa as it really was and, hence, as it really is (Fuglestad, 1992)

To point out the similarities between pre-colonial currents of African history and the patterns which are now emerging is not to argue that history repeats itself. There is, however, a historical concept which Braudel (1969: 41-83) called the longue durée, distinct from the shorter time-frames used in certain other types of activity, such as journalism or even diplomacy, whose subject is l'histoire événementielle. While a week may be a long time in the latter time-frame, the main flow of history changes only slowly. It would be simply mistaken to believe that Africa's older history was completely effaced by the creation of the colonial state and its development under independent African governments (Clapham, 1994). The older patterns survive, changed or even transformed, especially in the fabric of social institutions or forms of collective activity which were forbidden or discouraged by the colonial state or which lost their significance or prestige in the face of the modernizing programmes of both the colonial state and its successor - although there are also, we should add, social activities imported in colonial times, such as football clubs, which have become genuinely popular and formidable transmitters of collective identity. The colonial state was different from most pre-colonial African governments in its commitment to the notion of economic development and its aspiration to change the moral behaviour of its subjects. These modernizing programmes, implemented throughout SubSaharan Africa during the twentieth century, initially by the church and the state but later by the state almost alone, included the spread of literacy and Western medicine; Western technical education; the creation of bureaucratic, secular states with fixed boundaries; the adoption of modern forms of religious belief, implying conversion to a world religion and abandonment of witcheraft beliefs; and Africa's full integration into a monetized, world economic system. African nationalism took over these modernizing programmes from colonialism. Africa's current problems are closely connected to the widespread failure of such programmes to achieve what they were intended to do.

The failure of the modern forms of government and political mobilization implemented during the colonial and post-colonial period has produced an urgent need for new political arrangements. Hence Africans are currently inventing, cobbling together from pieces, or half-remembering from the past, new structures for government and political mobilization (Bayart et al., 1992). Moreover, the elites of modern Africa, overwhelmingly individuals, groups or families who achieved their position through domination of the state, are having to adjust rapidly to the weakening of the state and the privatization of economic activity urged upon them by foreign donors. Some elites are able to adjust to the new free trade systems fairly easily. Other governing elites can do so by using their control of state resources to relocate their influence in the private sector, by manipulating both the formal and the informal sector, or by representing themselves as leaders of civil society rather than political society, thus being better placed to receive aid-money. However the maintenance of political power through the private sector and in a multi-party system requires rather different techniques than in a oneparty state. There is a consequent rise in the use of new categories of largescale political mobilization. Outside South Africa, Namibia and Zimbabwe, nationalism, the great mobilizing ideology of the modern period in Africa, has greatly diminished as a means of political recruitment. This does not mean that nationalism as such has disappeared, since it remains prominent in public consciousness, especially in the cities (Coquery-Vidrovitch, 1992). To a large extent its place as an instrument of political mobilization is taken by appeals to ethnic solidarity, as political leaders struggle to locate categories useful for the organization of power in present circumstances. Ethnic mebilization in Africa lends itself easily to the democratization which has received moral and material support from Africa's main trading partners since 1989. Violence, as we have seen in former Yugoslavia and elsewhere, can be a formidable instrument of ethnic mobilization. The most extreme and malignant form of ethnic mobilization is genocide: it is now clear that the 1994 massacres in Rwanda were not the inevitable result of an age-old hatred but were planned and implemented by a small group of people who saw them as a means of retainıng power (Verschave, 1994: 23-4).

The subterranean shifts in African societies are also taking other pelitically significant forms. In particular, the rapid growth of religious movements of all descriptions throughout the continent, whether Christian, 
Muslim or other, has the capacity to endow the elusive qualities of authority and legitimacy on holders of power who lack these qualities at present. It is hard to overstate the importance of this development. After all, religion is, among other things, a symbolic representation of power, albeit one which has been consigned by the secular tradition of Western statecraft to the realm of private affairs. In Africa, religion is a public affair, and it very much occupies the state arena in the form of what are called in the West 'funda mentalist' movements. 'Fundamentalist', not a particularly exact description, is used as an adjective by Western commentators to designate any religious believer who refers readily to the scriptural bases of her or his belief such as the Koran or the Bible, particularly when the believer attempts to translate religious dogma into political action. The fact that many people in Europe or North America would not regard religion as a legitimate form of political mobilization is merely a sign of the extent to which Africans are searching among their own cultural roots for ways of living together in some kind of harmony, just as people are doing in many other parts of the world in view of the obsolescence of some of the ideologies and systems by which they have been governed for the last few decades.

Religion may provide the moral cement which, in time, will enable the construction of new political edifices. This could soon provide room for misunderstanding once more. It is already clear that the idea of a politically articulate Islam causes deep fear in Western countries of Christian tradition. What is less evident, but perhaps true none the less, is that the religion espoused by African Christians is also understood rather differently in the West, where the general public has ceased to have much beyond a vestigial religious belief, where the state is secular, and where even many church-goers have a quite different interpretation of Christianity from their African counterparts (ter Haar, 1995).

\section{NEW ECONOMIC PATTERNS}

The end of the Cold War has been accompanied by economic changes. Many parts of Africa's Atlantic coast are rediscovering a neo-mercantilist type of trading economy, whereby a string of cities along the coast, such as Lagos, Abidjan and Luanda, represent nodes of import-export trade at the point of contact between overseas and the African hinterland. They import goods from the industrialized world; they export raw products for the most part, from those enclaves of production which they succeed in controlling. Less than two hundred years ago - less than a century in some places Africa's staple exports were gold, slaves and ivory. Today, these have been superseded by oil, diamonds and even heroin, although gold, ivory and other commodities are still exported. Before the introduction of colonial minted currencies, African exports were often exchanged directly for European manufactures, especially cloth and small consumer items, guns
Africa ajter the cota war

and gunpowder, and liquor (Hopkins, 1973). Today, exports are sold for hard currency, and the range of imports is much wider. Nevertheless, for a European consul or trader in one of the cities of Africa's Atlantic coast today, the view is not so different from that seen by a predecessor sitting in one of the entrepôts which were scattered along the West African coast before 1900 and which formed the basis of so many modern cities.

Over the whole area south of the Sahara, power, whether commercial, political or other, is now best understood as being located in these nodal points, the great metropolitan areas which suck in wealth from outlying regions, irrespective of formal national frontiers, and whose sphere of influence is constantly changing in a complex overlap of visible and invisible frontiers. This is even the case with relatively developed South Africa (du Toit, 1993). Africans who find it difficult to earn a living at home in straitened circumstances may use the international networks emanating from the African metropolitan areas to seek work in the big cities of Europe and North America, keeping entire families back home solvent through remittances. Citizens of some African countries, such as Ghana, Nigeria and Senegal, are spreading out as fast as international immigration officials will allow them, forming international diasporas which also function as trade networks. Ethnic trade diasporas of this sort, although less far-flung in those days, were also a characteristic form of commercial organization in precolonial Africa (see Cohen, 1969; Gray and Birmingham, 1970; Meillassoux, 1971).

A hundred years ago there were very few large cities south of the Sahara except in West Africa, with its long tradition of urbanization, and South Africa, where European settlers have lived since the seventeenth century. Nowadays Africa's huge urban sprawls rival anything the world has to offer in terms of population. For the most part, and with the notable exception of the industrial Vaal Triangle around Johannesburg and one or two other areas in South Africa and Zimbabwe, cities south of the Sahara have a curious feature: they contain very little formal industry, but their inhabitants engage in a trading, artisan and service economy, sometimes combined with some farming either in town gardens, or in semi-urban plots, which gives many African cities a curious, half-urban, half-rural character. These vast, unregulated cities dominate their respective hinterlands. Even in late colonial times some country people, typically young men, went to the city for at least occasional employment. Colonial officials did their best to dissuade them from settling there permanently, particularly in the colonies of white settlement, by a battery of administrative interdictions and other disincentives. Now, however, there are whole generations of Africans born and bred in cities. Rich city-dwellers may buy farmland in outlying areas, raising landprices; city traders may tour the villages to buy food for urban markets (Bryceson and van der Laan, 1994).

People living in rural areas which are accessible to the big metropolitan power-centres cannot afford to forget that they are liable to the generally 
unwelcome attention of the security forces which, in many African countries, are far more likely to be used as clientelist networks adept at extracting tribute from local populations than as agencies to prevent crime or to defend the state against subversion. In these circumstances there are certain advantages to be had from living in remote areas, beyond the range of the metropolitan centres. People living in outlying regions are faced with a difficult choice between collaborating in their own subjugation by the extractive and coercive networks which constitute the state, or resisting, by paying tribute to rival power-centres or even setting up as power-centres in their own right under the protection of their own potentates or warlords. Probably the aspect of state intervention most appreciated by country people in the first decades after independence was the provision of schools and medical services in rural areas. The failure of the state has caused these services to break down in many countries, undermining the relationship between governors and governed.

The great metropolitan centres compete with each other for control of trade networks using any means at their disposal. Liberia, for example, is a theatre of conflict between the French-speaking states of the region, led by Côte d'Ivoire with its power-centre of Abidjan, and Nigeria, which aspires to West African hegemony. Rival warlords in Liberia, at least until the time of writing, loot what they can from the country, the major prize being the valuable, exportable resources of gold, diamonds, tropical hardwood and iron ore. A successful warlord in Liberia will exploit these resources using unpaid labour and sell them to merchants working for a syndicate based in one of the great regional cities, normally Abidjan or Lagos. The major syndicates, of course, can operate only with political protection from a suitably powerful faction (Ellis, 1995). Some observers believe that the wish to secure control of Liberian raw materials was one of the main factors behind the outbreak of the Liberian civil war in 1989 (Richards, 1995). Much of the skill of African politicians consists in deriving financial benefits from their external alliances and from the associated trade flows and using this capital to create or maintain a domestic clientele, a phenomenon known to some authors as 'extraversion' (Bayart, 1989/1993). This use of force to derive benefit from external trade is reminiscent of the policy of rival European commercial centres including Amsterdam and London which, in comparatively recent times, did not hesitate to encourage smuggling, counterfeiting and even piracy as a means of wresting control of important trade-routes (Rapp, 1975).

\section{AFRICA AND THE INDUSTRIALIZED WORLD: THE ROLE OF ELITES}

In many government and business circles outside the aid and development sector, Sub-Saharan Africa is increasingly viewed as being so marginal as to be hardly worth considering (Michaels, 1993). (In these circles, we could say, pessimism about Africa fills an ideological void as optimism does for development industry professionals.) The strategic importance which the Cold War gave to Africa has, for the most part, declined. For any dispassionate observer, that is a great boon; but it is a mixed blessing for African political elites, for while the Cold War militarized political disagreements, and turned purely domestic quarrels into international ones, it also made every part of Africa of potentially global significance and ensured a continuing flow of foreign funds and support which kept governments in power. The enlistment of African governments as clients of one or other Cold War protagonist was connected to the maintenance of clientelist networks within Africa itself. Aid, together with the rents to be derived from it and from control of the state generally, was the lubricant which kept African political machines in running order. Now that the Cold War is over, African governments are under pressure to dismantle the clientelist machines which kept them in power, or at least to reconstruct them on a different basis.

With more urgent problems to address, few governments outside the continent seem motivated to develop a coherent Africa policy beyond a pious exhortation to Africans to respect democracy and human rights. Even France, the former colonizer which has shown the most staying-power, is in disarray, obliged to devalue the CFA franc and under attack over its disastrous support for the former genocidal regime in Rwanda (Politique africaine, 1995). France has traditionally run its African zone of influence on a protectionist basis (Marseille, 1984). Now, the Africa policy of the French government finds itself squeezed between US power, the imperatives of European integration and the decline of its traditional alliances in Africa itself. In what has been referred to as 'the near-total absence of coherent North-South strategy formulated by anybody else' (George and Sabelli, 1994: 1), it is the Bretton Woods institutions, and especially the World Bank, which are left in occupation of the field. It is they which articulate most elearly the policy of the industrialized world towards Africa, based on free rade and liberal politics.

While some African elites are amenable to free trade and even to a slimmed-down state, others struggle to adapt as political bargains made in the past cease to satisfy. Nigeria is an important example: with a population of almost 90 million people, Nigeria is the world's tenth or eleventh-largest producer of oil (in an average year), revenue from which is the greatest source of income for its government. The oil wells are situated in the south of the country, especially in the Niger delta region. The Nigerian government has been dominated since independence by elites from the north of the country, whose access to the oil wealth goes through the state. Moreover, the northern elites are now seemingly dependent on their control of the army rather than on any formal or democratic political structure to maintain their possession of this manna. A restructuring of Nigerian government or the sharing of the oil-revenues between regions on a more equitable basis is perceived as a threat to their control of 'the national cake'. As long as the oil 
keeps flowing, there is a possibility that Nigerian political elites can renegotiate their relationships with each other in a manner which will keep the country intact and avoid violence. If they are unable to strike satisfactory bargains, however, the country's future looks bleak: the northern military elites cannot prosper or raise sufficient capital to buy the support of other Nigerian elites without having a controlling interest in a state which enables them to have access to the oil revenues of the south (Naanen, 1995).

\section{COLONIALISM IN CONTEXT}

The reimposition of free trade in Africa, combined with the continent's internal political developments, in some respects represents the end of an era. As historians of the colonial period long ago observed, free markets are by no means incompatible with the existence of distinct zones of influence by those powerful industrial nations whose goods dominate them, making formal political control unnecessary (Gallagher and Robinson, 1953). There is a clear line of continuity between the mechanisms by which Africa was connected to the world economy in the mid-Victorian era of free trade, the scramble to divide the continent into formal zones of imperial control, decolonization, and now the new assertion of free trade. The current effort to reorganize Africa's political economy through aid or loan conditionality is not the industrialized world's first attempt to reconstruct the continent's political and economic infrastructure (that is, states and markets, or the lack of them) in a manner appropriate to the needs of modern business or of commerce in the broadest sense. Modern African elites, in many cases the product of these massive attempts at political engineering, understand that their survival depends on their ability to take local control of the new attempts at restructuring.

Prior to its colonization, Africa was occupied by thousands of sovereign political entities varying in size. That was not a problem - indeed it may have been an advantage in some respects - for foreign traders who wished only to buy a resource such as ivory or slaves which needed no capital investment for its exploitation. However, the expansion of modern business interests, especially the so-called 'legitimate' trade in raw materials which replaced the slave trade, placed a premium on the existence of responsible public authorities with which bargains could be made and binding contracts signed, and to which bank loans could be offered (Cain and Hopkins, 1993: 351-96). Thus, one of the results of the assertion of imperial control of Africa south of the Sahara was ultimately 'the establishment of some forty-eight new states ... in place of the existing innumerable lineage and clan groups, city-states, kingdoms, and empires without any fixed boundaries' (Boahen, 1987: 95). It was not of course the colonialists' intention to produce independent nation-states, but by the mid-twentieth century that was a development broadly acceptable to powerful interests in the industrialized world. The new states which emerged at independence were structured in the modern manner, that is to say the one evolved in Europe from the seventênth century onwards, and subsequently exported to North America and elsewhere. As we have said, the nation-states of modern Africa which are in such difficulty at present, were to a considerable extent brought into existence by Europeans and other outsiders, in the acts of colonization and decolonization. The real end of the colonial order is thus intimately connected to the present crisis of African states.

- There are a number of theories which try to explain why, during the nineteenth century, some European countries sought to impose formal political control over the African continent, when they had previously been satisfied with a measure of informal influence (Owen and Sutcliffe, 1975). Whatever the specific factors which determined the timing of colonization in different parts of the continent, businessmen and imperial pro-consuls required interlocutors in those parts of the world which they penetrated. They sought middlemen who could be entrusted with credit, and potentates xho would enforce contracts and provide physical security. Once colonial overnments had been established, the colonial masters also required labourers who would produce the commodities for colonial trade, consume the products of the metropole, and pay the taxes which would enable the eolonial administration to perpetuate itself. They needed clerks and interfreters and soldiers, and more besides. The larger the scale of the investment in a colony, or the longer the time required for a satisfactory rate of return, the more sophisticated was the nature of the co-operation required by colonalists from African allies or partners. Whereas it was possible to buy ivory or palm-oil from a local chief, investment in a mine or a railway company created different demands altogether. The attempt to create modern mechanized production in tropical Africa, which was characteristic of the late colonial and post-independence period, involved even more sophisticated requirements for public institutions and commercial systems which could articulate with those of the rich countries. These may be summed up in the general sense of the word 'development' as used in the African context.

The need to identify or even to create local elites which would be partners or allies for officials or traders from the imperial metropolitan countries was one of the major underlying themes of imperialism, and indeed there have been attempts to explain the chronology of imperialism in terms of changes in the nature of the relationship between imperialists and their local allies (Robinson, 1976). Writing at a time when nationalism was still the standard deology of African elites, Ranger (1968) was able to trace connections between patterns of early resistance to colonization and modern nationalist novements. Scholars investigating the concept of neo-colonialism have used the same type of analysis, underlining the relations between political or business interests in the rich world and their partners in Africa, the local 'pseudo-bourgeoisie' (Amin, 1971: 89-90). It was possible to consider the hationalist elites which were to run Africa after independence as essentially 
in partnership with colonial interests (Fanon, 1967). In less polemical terms, the notion that, broadly speaking, interests in the rich world required local elites in Africa with which they could co-operate, and which would in turn establish a relationship with the people whom they governed, offers the possibility of studying the imperial factor over an extended period, and has the advantage of getting to grips with at least one aspect of the historical longue durée.

The imposition of colonial rule and the creation of conditions suitable for colonial business required a major reorganization of Africa's social and political infrastructure, if necessary by the use of force. Decolonization was a rather hasty attempt to reorder the colonial system in the light of the world order which took shape after 1945, when super-powers emerged which were opposed to the maintenance of the European colonial empires in Africa and Asia, and which were powerful sponsors of awakening nationalist movements in Africa itself. A vital element of continuity between the old colonial powers and the newly independent African states was the relationship between European former imperial interests and elites in Africa. This relationship was renegotiated, but only rarely ruptured, at the time of independence. For African elites to carry out their share of the bargains they had made with imperial economic or strategic interests they had to be able, in turn, to reach agreements and make deals of every description with sub-national elites. After independence, they had to govern. Hence, decolonization represented a reordering of the complex series of bargains which linked African economies with the international economic systems dominated by the rich world. Now, the super-powers have disappeared or lost interest in Africa. The difficulties faced by a number of African states in recent years have profoundly disrupted the networks of relationships both within Africa and overseas.

During the Cold War political struggles within Africa would occasionally produce disquiet in Washington, Moscow or elsewhere as commentators tried to assess whether certain rulers were pro-Western or pro-Soviet. Different factions of African elites, or even the same individual, would play on this to extract the maximum advantage to themselves by threatening to turn to a rival power. Armed movements of insurrection, generally calling themselves liberation movements, might rise up to contest governments, with a view to taking state power themselves. These too generally needed foreign partners (Reed, 1993). None of the liberation movements in Africa ever aimed to destroy the state apparatus, the means by which the country could be governed and wealth could be acquired. Their aim was to take control and use the apparatus for their own purposes. Which, when they were successful, is exactly what they did.

Just as the end of the Cold War marked the true end of the European order established in 1945, so it marked the real end of the colonial order in Africa. It is the final demonstration of the fact that, contrary to what has sometimes been argued (Robinson and Gallagher, 1961), the true roots of the colonial division of Africa lay in rivalry between industrial powers in the first place.

\section{THE REAL POST-COLONIAL ORDER}

Africa is subject to the same forces of 'globalization' as other parts of the world (Featherstone, 1990). Africans must seek whatever means are available for participating in the world economy, even, in the absence of more profitable means of legal commerce, by trading in illegal narcotics (Cesoni, 1992). African elites are more cosmopolitan than ever before. A large proportion of the African elite, probably 100,000 or more with university degrees or high-level skills, are living and working in the developed world (Ricca, 1989: 91-105). But while African elites have become ever more globally integrated, the same is not true of their fellow-countrymen. Much of central Africa, for example, is now more isolated geographically and in other tespects than at any time since the early colonial period. This is largely because African elites have lost their grip over the states which they had used as their instruments. In Somalia, for example, the state (not merely an incumbent government), has effectively collapsed. The physical infrastructure of offices, telephones, electricity and piped water has gone. There is no functioning police force, no army or law courts. The longer this situation continues, the more young Somalis will reach adulthood without formal education, technically unequipped to run a modern state even if one existed. At present, even if the international community were to recognize one or another rival warlord as the legitimate president of the country, it would make little difference unless that gesture was accompanied by a large-scale rehabilitation programme such as that envisaged by the United Nations and the United States at the time of their intervention in 1992 (Marchal, 1994). This does not mean that Somalia has become the locus of unspeakable anarchy: on the contrary, Somalis have reacted to the lack of a modern state by reviving or inventing a range of mechanisms to regulate their society, including the traditional clan and sub-clan structures and their common heritage of Islam. This is interesting precisely because it is an indication of the options available in at least some parts of Africa to replace the orthodox forms of the state.

As a result of the failure of the US/UN intervention in Somalia, the World's leading powers have decided that the chaos in that country, regrettable though it may be, does not threaten their vital interests. The rich world appears to have made the same judgement in the case of Liberia. In circumstances like these, the World Bank, understandably, will not contemplate making any loans, and a country is left to its own devices. Such an atitude on the part of decision-makers and opinion-formers in the rich world may appear to be a triumph of Realpolitik over sentiment, to be applauded or condemned according to taste. Even if the argument is stated in these terms, however, there are grounds for wondernng how realistic a policy of abandonment is. One consequence of leaving Somalia or Liberia to their own devices is that if, at some stage in the future, a foreign power were to decide that it wished to exercise major influence there, such as to exert 
control over an important mineral deposit, to safeguard an environmental resource or to protect a strategic position, it will find that the machinery which makes the territory responsive to the will of outsiders no longer exists, and nor does the type of elite which is required to run a state machinery. As we have seen, the establishment of such a human infrastructure was one of the main consequences of Africa's colonization. A modern state, after all, consists of people - public administrators in particular - who are required to possess certain skills and to have mastered certain codes of behaviour. If such people do not exist, or are not able to combine effectively enough to carry out the tasks that outside powers require of them, even the application of large amounts of money might not be effective as a means of exerting control. As has been demonstrated in Somalia, throwing money and resources at a problem of this nature, once a state has collapsed, may have the effect of providing incentives for renewed factional rivalry, thereby encouraging further war and disruption.

We may illustrate this by taking a specific example. The south of Chad contains oil reserves substantial enough to warrant commercial exploitation by major Western oil companies (Faes, 1995). Since these reserves are located in a land-locked area, any company wishing to produce oil for export will need not only to invest in oil-wells, but also to build a pipeline to the coast through neighbouring Cameroon. Chad has been chronically unstable for over twenty-five years. The government of Cameroon is notoriously corrupt and has also become unable in recent years to keep firm control of the national territory. It is opposed by various groups, many of them regionally based, and the main roads in the north of the country in particular are liable to bandit attack. In these circumstances a company considering a major investment in the Chadian oil-fields and the associated pipeline must make a calculation in which the initial investment, perhaps running into hundreds of millions of dollars, is weighed against future profits, operating costs and overheads, and royalties to be paid to the authorities in Chad and Cameroon. That in itself is an operable calculation. The snag is that the payment of large royalties, given the circumstances now prevailing in the region, might well aggravate the political-military conflicts in the two countries, thus increasing the insecurity which is so bad for business. In the end, an interested company must make one of three broad choices: either to abandon the project altogether as too risky, and forego Chad's oil; to go ahead, taking precautions but knowing that the risks of instability and financial loss are quite high; or to lobby their own, Western governments to try to stabilize the politics of Cameroon and Chad. The last option is now becoming less realistic as the state apparatuses of Africa erode, making the articulation of political influence on a large scale more difficult

Even if decision-makers in the rich world believe that problems of political control in certain African countries do not affect their own interests in the foreseeable future, and if they are not sufficiently motivated by humanitarian concerns to intervene, they cannot be so sanguine about the risks posed by certain parts of the continent. For example, the Rwandan tragedy, apart from being one of the worst catastrophes in the world since 1945, has the potential to disrupt the whole Great Lakes region of Africa, one of the continent's most populous and most productive areas. With the Great Lakes to the west, and Somalia to its north, such a situation would pose a threat to Kenya, one of the few African countries which is generally considered to be of substantial commercial or strategic value to at least some parts of the industrialized world.

-Above all, there is Algeria. This is a relatively developed country, which some years ago was rumoured to be close to possessing nuclear weapons. It is situated on the southern flank of the European Union, a short boat-trip from Spain, Italy or France, where millions of people of Algerian origin now live. Algeria was constitutionally a part of France for over a hundred years, and the wounds of the terrible war of independence have not yet healed in either country. The current insurrection in Algeria has cost an estimated 30,000 Ives since 1992, when the government, with support from France in particutar, cancelled elections which the Front Islamique de Salut (FIS) was on the point of winning. The insurgents have an authentic internationalist ideology, that of militant Islam. They are systematically and brutally setting out to dêstroy people whom they regard as collaborators with the colonial state, those in current positions of power, those who speak French, women who tefuse the veil, and all those who refuse their vision of an Islamic theocracy (Leveau, 1995). It seems likely that the current government in Algiers will, in time, be overthrown. Even if it manages to survive, the consequences of the escalating violence will certainly include increased political difficulties in neighbouring countries including Tunisia, Egypt and Morocco; the moveinent of large numbers of refugees towards southern Europe; terrorist activity among North African communities in France especially, with the tisk of a violent reaction by French right-wingers; and a shift in the balance of power throughout the Muslim world, in a sense not favoured by Europe or North America. NATO has already offered co-operation to some North African governments considered to be threatened by popular insurrection, in a way which makes it clear that militant Islam is well on the way to being ciassed by European leaders as a primarily military problem.

North Africa may be regarded as a special case, different from SubSaharan Africa, closer to Europe, essentially isolated from the rest of the continent. In reality, North Africa is a part of the African continent, in constant intercourse with its southern neighbours, in spite of the geographteal barrier of the Sahara. In post-colonial circumstances, old links neglected in recent decades may be revived once more. One of the main forms of pelitical and cultural communication between north and south of the Sahara hias been through Islam, although the development of Islamic networks was stymied by the imposition of imperial rule by European powers with Chrisfian and secular traditions. The withdrawal of the latter, naturally enough, is ikety to encourage the development or revival of old Islamic networks. 
In Africa both Christianity and Islam are being used as symbolic languages adapted to political mobilization, a further consequence of the decline or failure of socialism, nationalism, 'development' and other secular ideologies. There is nothing more traditional than the use of religion in Africa (and in many other parts of the world) as an instrument of political order. Furthermore, while both Christianity and Islam represent complex and genuinely international ideologies, they are also rooted at the local level in small communities which find in religion the sense of moral community and spiritual reassurance which is lacking in African national politics. Religious institutions sometimes offer facilities for education and health, which failed secular states are increasingly unable to do (Tozy, 1995). The most rapidly growing strains of Christianity, generally pentecostal and charismatic churches, have thriving relations with groups of similar persuasion elsewhere, for instance in the USA, in Latin America and in South Korea (Gifford, 1993, 1994). Some African congregations even send missionaries to Europe in a striking reversal of the historical pattern of evangelization (ter Haar, 1995). Membership of a Muslim congregation similarly brings access to a worldwide network of faith. Muslim militants, even the poor who are generally excluded from the global society based on consumption, are able to identify with a vision of the world whose points of greatest friction are the struggles in Palestine, Chechnya, Bosnia and Afghanistan (where numbers of young African Muslims served as volunteer fighters), all of which are represented in Muslim countries as primarily religious struggles. The countries of the Maghreb are closely connected to their neighbours south of the Sahara by ties of this sort.

Most European politicians, journalists and writers perceive the growth of international Christian fundamentalism as a bizarre and possibly spurious tendency, despite the fact that it was Europe which originally exported Christianity to the world in a formative act of global articulation. The widespread failure of Europeans to understand this phenomenon today is a measure of the degree to which European elites in particular have lost touch with the emerging political language of the world's poor. Interestingly, the same is not true of the USA, where a significant section of the political establishment and the general public seems able to understand international politics in terms of religious symbolism. In the emerging contest between the Christian and Muslim worlds, Africa is an important site of rivalry. If, as is sometimes speculated, the cardinals of the Roman Catholic church were to choose an African as the next Pope, the effect would be to bring this struggle to public attention for the first time (Michaux, 1995).

Islam, on the other hand, is not a Western export and throughout Africa was frequently in opposition to the colonial state and to the African elites produced by colonialism. This also makes it an appropriate ideology for populations who have suffered from 'development', at least in the form it was presented to them throughout the colonial and post-colonial periods. In general terms, Somalia, Algeria, Rwanda, Burundi, Liberia and others can ill be said to represent failures of the model of development as it was generally conceived of from the $1950 \mathrm{~s}$. This does not mean that Africans do Hot want to get richer or to have access to more advanced technology. The ckidence suggests that virtually everyone in Africa desires the enhanced standard of living which programmes of development are supposed to etcourage. But these programmes have been applied in such a form as to teate strong resistance in some places. It is not inconceivable that even such apparently obscurantist ideologies as Christian or Islamic fundamentalism nay be able, in the future, to harness the technical skills required to create economic growth. After all, we have seen in the case of East Asia that growth can occur in societies which combine certain technical skills with aspects of loeal culture in a way which was thought impossible four decades ago, when growth was widely believed to be possible only by the assumption of Western models of behaviour (see, for example Rostow, 1953, 1960). If Algeria acquires an Islamic government there is no guarantee that, in time, the lstamic cultures of North Africa might not produce an economically and technically advanced culture which is also profoundly anti-European, antisecular and anti-Christian.

Algeria merely illustrates a general truism: that it is not possible for the tich world, in the long term, simply to abandon Africa to political instability ard economic immiseration without damage to itself. Just as the USA is not able to ignore misery in Haiti or Mexico, so Europe cannot ignore misery in Aftica, not even south of the Sahara. Europe has a long historical relationshipwith this continent whose population will shortly reach a thousand intion.

\section{CONCLUSION}

-3:

Some writers represent the post-Cold War order in terms of privilege and exclusion. Europe is represented as an analogy with the late Romans, fearing the populations outside their borders which were eventually to destroy the Empire (Rufin, 1991). The whole of the rich world is compared to the driver of a luxurious limousine, driving through crowds of beggars who are banging jeal ousty on the doors (Kaplan, 1994). These are disturbing images. Western infelligence agencies and security services, looking for new menaces to replace the old Soviet bogeyman, have been among the most avid pedlars of scenatios of conflict between European or North American prosperity and a situation of anarchy on its southern border generating terrorism and violence and strengthening an international nexus of crime.

These suggestions may be fairly regarded as the exaggerated inventions of ournalists in search of sensation or special interest groups seeking to justify their own existence. In the modern world, the images transmitted to mass audiences by mass media are invariably connected to the power wielded by specific groups and to the generation of profits (Smith, 1980). However, if 
Faes, G. (1995) 'Tchad: oléoduc via le Cameroun', Jeune Afrique 1779: 32.

Fanon, F. (1967) Black Skin, White Masks. New York: Grove Press.

Featherstone, M. (ed.) (1990) Global Culture Nationalism, Globalization and Modernity. London: Sage.

Fuglestad, F. (1992) 'The Trevor-Roper Trap or the Imperialism of History: An Essay', History in Africa 19: 309-26.

Gallagher, J. and R. E. Robinson (1953) 'The Imperialism of Free Trade', Economic History Review (2nd ser.) VI(i): 1-15.

George, S. and F. Sabelli (1994) Faith and Credit: The World Bank's Secular Empire. London: Penguin.

Gifford, P. (1993) Christianity and Politics in Doe's Liberia. Cambridge: Cambridge University Press.

Gifford, P. (1994) 'Some Recent Developments in African Christianity', African Affairs 373: 513-34.

Gray, R. and D. Birmingham (eds) (1970) Pre-Colonial African Trade: Essays on Trade in Central and Eastern Africa before 1900. London: Oxford University Press.

ter Haar, G. (1995) 'Strangers in the Promised Land: African Christians in Europe', Exchange 24(i): 1-33.

Heidenheimer, A. J., M. Johnston and V. Levine (eds) (1989) Political Corruption: A Handbook. New Brunswick, NJ: Transaction Publishers.

Hobsbawm, E. (1994) Age of Extremes: The Short Twentieth Century, 1914-1991. London: Michael Joseph.

Hopkins, A. G. (1973) An Economic History of West Africa. London: Longman.

Joseph, R. (1987) Democracy and Prebendal Politics in Nigeria: The Rise and Fall of the Second Republic. Cambridge: Cambridge University Press.

Kaplan, R. D. (1994) 'The Coming Anarchy', Atlantic Monthly: 44-76.

Leveau, R. (ed.) (1995) L'Algérie dans la guerre. Brussels: Éditions Complexe.

Leys, C. (1994) 'Confronting the African Tragedy', New Left Review 204: 35-47

Marchal, R. (1994) 'Somalie: les dégâts d'une improvisation', in M.-C. Smouts (ed.) L'ONU et la guerre: la diplomatie en kaki, pp. 77-101. Brussels: Éditions Complexe.

Marseille, J. (1984) Empire colonial et capitalisme français. Paris: Albin Michel.

Médard, J.-F. (1991) 'L'État patrimonial en Afrique noire', in J.-F. Médard (ed.) États d'Afrique noire: formation, mécanismes et crise, pp. 323-53. Paris: Karthala.

Meillassoux, C. (ed.) (1971) The Development of Indigenous Trade and Markets in West Africa. London: Oxford University Press for International African Institute.

Michaels, M. (1993) 'Retreat from Africa', Foreign Affairs 72: 93-108.

Michaux, S. (1995) 'Le prochain Pape sera-t-il africain?', L'esprit libre (France) 3: 6-10

Mistry, P. (1994) Multilateral Debt: An Emerging Crisis? The Hague: Fondad.

Naanen, B. (1995) 'Oil-Producing Minorities and the Restructuring of Nigerian Federalism: The Case of the Ogoni People', Journal of Commonwealth and Comparative Politics XXXIII(i) 46-78.

Non-Aligned Group (1994) The Continuing Debt Crisis of the Developing Countries. NonAligned Movement.

North, D. C. (1990) Institutions, Institutional Change and Economic Performance. Cambridge: Cambridge University Press.

Owen, R, and B. Sutcliffe (eds) (1975) Studies in the Theory of Imperialism. (2nd edn) London: Longman.

Politique africaine (1995) No. 58 'Mitterrand et l'Afrique'. Paris: Karthala.

Putnam, R. D. (1993) Making Democracy Work . Civic Tradittons in Modern Italy. Princeton, NI: Princeton Unversity Press.

Ranger, T. O. (1968) 'Connexions Between "Primary Resistance" Movements and Modern Mass Nationalism in East and Central Africa', Journal of African History IX(iil): 437-53, and IX(iv): $631-41$. app, R. T. (1975) 'The Unmaking of the Mediterranean Trade Hegemony: Rivalry and the Commercial Revolution', Journal of Economic History $\mathrm{X}$ Reed, W. C. (1993) 'International Politics', and National Liberation: ZANU Contested Sovereignty in Zimbabwe', Afrucan Studies Review 36(ii): 31of Charles Taylor's NPF Iournal XVIII(ii): 175-87.

Reyntjens, F. (1994) L'Afrique des Grands Lacs en crise. Paris: Karthala.

Ricca, S. (1989) International Migration in Africa: Legal and Administrative Perspectives. - Geneva: International Labour Organization.

Richards, P. (1995) 'Sierra Leone and Liberia: A Crisis of Youth?', in O. W. Furley (ed.) Conflict in Africa, pp. 134-70. London: Tauris Academic Studies.

Robinson, R. E. (1976) 'Non-European Foundations of European Imperialism: Sketch for a Theory of Collaboration', in W. R. Louis (ed.) Imperialism: the Gallagher and Robinson Controversy, pp. 128-52. New York: New Viewpoints.

Rrobinson, R. and J. Gallagher with A. Denny (1961) Africa and the Victorians: The Officia - Mind of Imperialism. London: Macmillan.

Rostow, W. W. (1953) The Process of Economic Growth. Oxford: Clarendon Press.

Rostow, W. W. (1960) The Stages of Economic Growth: A Non-Communist Manifesto. Cambridge: Cambridge University Press.

Rulfin, J.-C. (1991) L'Empire et les nouveaux barbares. Paris: J.-C. Lattès.

Sklar, R. (1983) 'Democracy in Africa', Presidential Address to the 25th annual meeting of the African Studies' Association, Washington DC (November 1982). Printed in African Studies Review 26(iii-iv): 11-24.

Snith, A. (1980) The Geopolitics of Information: How Western Culture Dominates the World London: Faber and Faber.

d4: Toit, A. (1993) 'Understanding South African Political Violence: A New Problematic?' Discussion Paper 43. Geneva: United Nations Research Institute for Social Development.

10. '. (1994) 'Structural Adjustment: Context, Assumptions, Origin and Diversity', in R van der Hoeven and F. van der Kraaij (eds) Structural Adjustment and Beyond in Sub-Sahara ifrica, pp. 18-35. The Hague, NL: Ministry of Foreign Affairs; London: James Currey fortsmouth, NH: Heinemann.

67). M. (1995) 'Movements of Religious Renewal', in S. Ellis (ed.) Africa Now: People, Politics and Institutions, pp. 58-74. The Hague, NL: Ministry of Foreign Affairs; London: Jame Eurrey.

trop. A. M. (1994) 'Gender, Political Participation and the Transformation of Associational iife in Uganda and Tanzania', African Studies Review 37(i): 107-32

United" Nations Conference on Trade and Development (UNCTAD) (1994) 'Trade and Development Report 1993'. Geneva: UNCTAD.

erschave, F.-X. (1994) Complicité de génocide? La politique de la France au Rwanda. Paris: La Decouverte.

Wortd:Bank (1989) Sub-Saharan Africa: From Crisis to Sustainable Growth. Washington, DC World Bank.

Worti Bank (1994a) Adjustment in Africa: Reforms, Results and the Road Ahead. New York Oxiord University Press for the World Bank.

Wortc Bank (1994b) Reducing the Debt Burden of Poor Countries: A Framework for Action. Washington, DC: World Bank. 